\title{
Ensuring the Sustainable Development of Hotel Establishments by Improving the Service Quality
}

\author{
M.V. Kobyak, S.S. Skobkin, Aghiad Makhlouf*, George Jarrouj \\ Department of Hospitality, Tourism and Sports Industry, Plekhanov Russian University of Economics, Moscow, Russia. \\ *Corresponding author. Email Mahluf.A@ rea.ru
}

\begin{abstract}
This article discusses the concept of sustainable development of hotel enterprises and methods to ensure it by improving the quality of hotel services. This research work is very relevant, since at present much attention is paid to the sustainable development of tourism and hotel enterprises, since sustainable development has a great influence on improving the efficiency of the country's economy and is very important for any state and in any conditions.
\end{abstract}

Keywords: sustainable tourism, sustainable hospitality, hotel enterprises, hotel services, service quality, economic, environmental, social, institutional, ICT

\section{INTRODUCTION}

Sustainable development is defined in many ways, but the most common definition is "our common future", which means meeting the needs of the present without compromising the needs that provide a balanced and healthy life for future generations in the future, and this concept first appeared in (1987) in Report Issued by the Brundtland Commission, which warns of the environmental risks of economic growth, globalization, population growth and industrialization, and is trying to find appropriate solutions [12]. The goal of this research work is a comprehensive study of ensuring the sustainable development of hotel enterprises on the basis of improving their service quality, as well as the development of a set of scientific and practical recommendations for improving the sustainable development of hotel enterprises on the basis of increasing their competitiveness.

\section{SUSTAINABLE DEVELOPMENT OF THE HOTEL ENTERPRISES}

The modern concept of sustainable development includes four main aspects [14]: economic, social, environmental and institutional, as shown in Figure 1.

In our opinion, it is necessary to add a new aspect to the already existing aspects of sustainable development, since at the present stage, a new economy is developing, which requires innovation. The author proposes aspects of sustainable development presented in Figure 2.

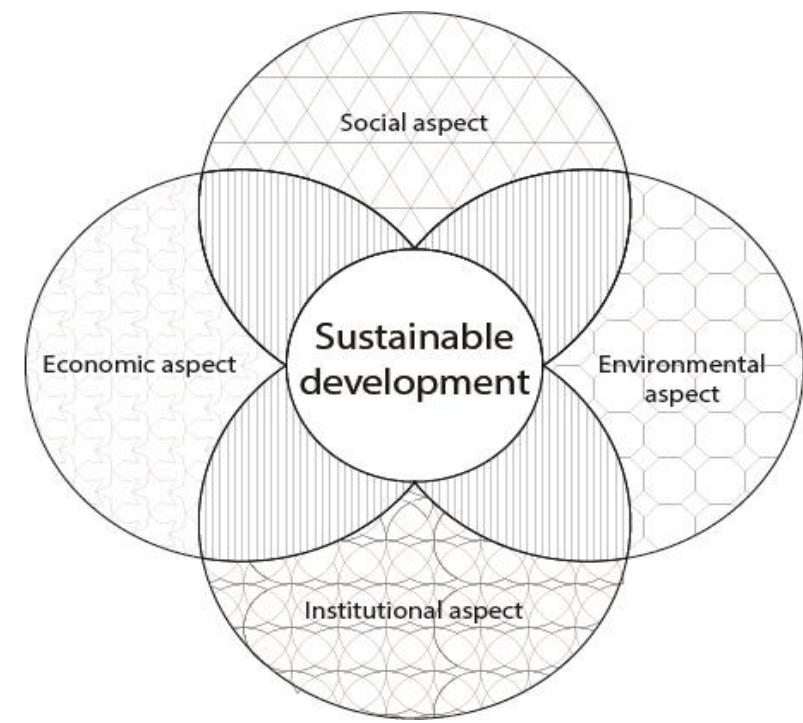

Figure 1 Aspects of sustainable development

Source: Compiled by the author based on the UN Development Program.

It should be noted that so far in the world community, the main international organizations are developing criteria and indicators of sustainable development.

According to the World Tourism Organization (WTO), sustainable tourism development is "tourism that takes full account of its current and future economic, social and environmental impacts, satisfying the needs of visitors, industry, the environment and host communities". The World Tourism Organization (WTO) is the developer of the first methodology for assessing the sustainable development of tourism [14]. 


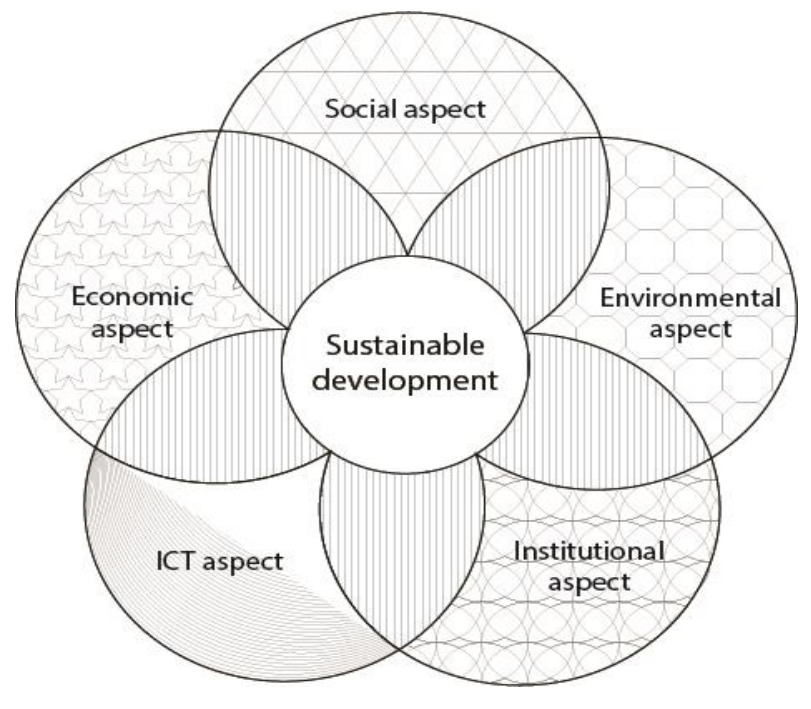

Figure 2 Sustainability aspects proposed by the author Source: Designed and Compiled by the Author

The essence of this approach lies in the system of indicators, and consists of 768 indicators, 29 of which are basic. In this regard, the criteria and global basic standards for the tourism industry, which are managed by the Global Council on Sustainable Tourism (GSTC), are presented. There are two sets: appointment criteria for government policy makers and line managers, and industry criteria for hotels and tour operators. According to the GSTC, the criteria for sustainable development for hotels and tour operators are the same and identical to the industry criteria of the GSTC. This demonstrates the close relationship between sustainable development in the hotel and tourism sectors. The criteria for hotels were created in order to come to a common understanding of the sustainable development of tourism and are the minimum that the hotel business should strive to achieve. Based on data from the Global Council on Sustainable Tourism Development (GSTC), the main criteria for sustainable development of the tourism industry for tourism destinations are closely related to the following factors:

- Rational and effective planning of sustainable development of tourist destinations.

- Focusing on maximizing the socio-economic benefits received by the local population.

- Strengthening of cultural heritage.

- Reduction of harmful and destructive effects on the environment [13].

It should be noted that there are still no clear criteria in the world community and no methodology for assessing the sustainable development of hotel enterprises.

According to S.S. Skobkina, the final stage of planning sustainable development of tourism should be measures to improve the territory where tourism is under development in a cluster of hospitality services [11, p. 80-81].

In our opinion, the sustainable development of hotel enterprises involves the simultaneous solution of diverse and largely controversial problems of economic growth in the hotel industry, provided that the quality of the living environment is maintained, assessed primarily in accordance with the following aspects: social, economic, environmental, institutional and informational communication technology.

In our opinion, the objectives of sustainable development of hotel enterprises should be as shown in Figure 3.

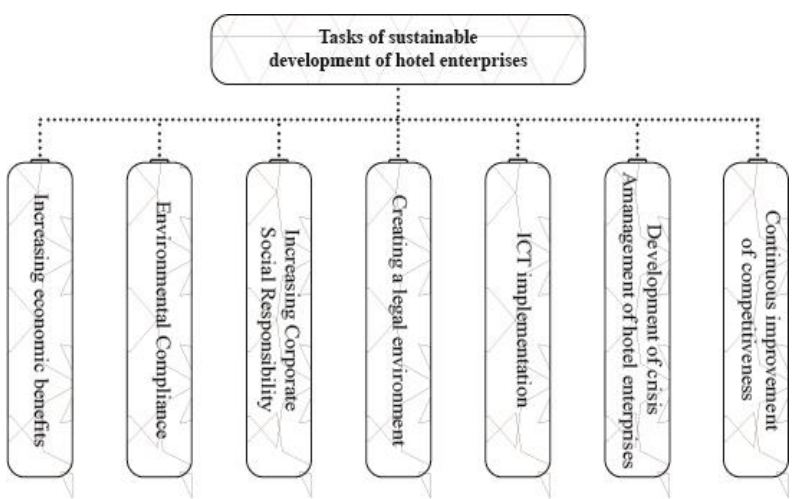

Figure 3 Tasks of sustainable development of hotel enterprises

Source: Compiled by the author.

Let's consider them in more detail.

1. The increase in economic benefits for both hotel enterprises and for the local population, based on the following tasks:

- Quality management and ensuring the development of the service of hotel enterprises [1, p.8-9].

- financial sustainability management of hotel enterprises.

- an increase in investment opportunities in the hotel industry, which, in turn, leads to an increase in the contribution of hotel enterprises to GDP.

2. Increase in corporate social responsibility (CSR) of hotel enterprises. Social responsibility in the field of hotel enterprises is the adoption of a social role in the development strategies of hotel enterprises, which will bring much benefit to the community, improving the mental image of the organization and creating a positive look for hotel guests, employees and community members as a whole $[5$, p. 65-66] .

3. Compliance with environmental standards when providing hotel services: measures are being taken to minimize risks to the territory and the environment in which the hotel is located.

4. The creation of a legal environment for hotel enterprises aimed at supporting the social, environmental and cultural aspects: laws and regulations are issued by the state or by the hotel enterprises themselves with the aim of creating a legislative environment that ensures the achievement of sustainable development goals [1, p.13-14].

5. The introduction of ICT for the effective control and management of hotel enterprises [10, p. 474-475]. One of the most important reasons for the increasing demand for hotel enterprises is the progress in the field of information and communication technologies, which provide good communication between exporting countries and host tourists, and also play a large role in the provision of tourism and hotel services [6, p.175-176]. 
6. Development of crisis management of hotel enterprises. A simple definition of the crisis in the field of tourism and hospitality is that an unexpected event affects the confidence of tourists traveling to a particular tourist destination [9, p. 65-66]. Crisis management in the field of hospitality involves the development of strategies for dealing with crises and conditions of instability, which must be divided in accordance with the crisis stages and extended also to the post-crisis period [7, p.113-114].

7. Constantly increasing the competitiveness of hotel enterprises. The term "competition" ("concurrere") literally means "clash" or "compete" [2, pp. 20-21]. From an economic point of view, competition can be defined as a competition among market participants for obtaining the most favorable conditions and results of economic activity [8, p.204-205].

\section{CRITERIA FOR ASSESSING THE SUSTAINABLE DEVELOPMENT OF HOTEL ENTERPRISES}

Based on the selected criteria for sustainable tourism development for destinations proposed by the Global Council for Sustainable Tourism (GSTC), the author proposes a classification of criteria for assessing the sustainable development of hotel enterprises with five sections, which are presented in table 1 .

Table 1. Criteria for the sustainable development of hotel enterprises proposed by the author.

\begin{tabular}{|c|c|}
\hline \multicolumn{2}{|r|}{ Section A, increasing economic benefits for both the hospitality industry and the local community } \\
\hline A1 & $\begin{array}{l}\text { Room Revenue - revenue from sales for a room fund. } \\
\text { The indicator is calculated as the total revenue from the room fund, net of taxes and food expenses. }\end{array}$ \\
\hline $\mathrm{A} 2$ & Occupancy - loading is equal to the number of sold numbers divided by the total number of numbers. \\
\hline A3 & $\begin{array}{l}\text { ADR is the average price per room. ADR is equal to the proceeds from the sale of room stock divided } \\
\text { by the number of rooms sold. }\end{array}$ \\
\hline A4 & $\begin{array}{l}\text { Double Occupancy - this indicator is taken into account when forming the budget. Double Occupancy } \\
\text { equals the number of guests / occupied rooms }\end{array}$ \\
\hline A5 & RevPar = (Room Revenue - Room Revenue $) /$ total number of rooms in a hotel \\
\hline A6 & $\begin{array}{l}\text { RevPAC - income per guest. RevPac = (total hotel income, including accommodation, meals, additional } \\
\text { services, taxes / number of guests staying for a given period). }\end{array}$ \\
\hline A7 & $\begin{array}{l}\text { The financial stability ratio is a ratio equal to the ratio of equity and long-term liabilities to the balance } \\
\text { sheet currency. }\end{array}$ \\
\hline A8 & $\begin{array}{l}\text { Profitability ratio of hotel enterprises (net profit). } \\
\text { Obtained by dividing the profit from the sale of services by the amount of revenue received. }\end{array}$ \\
\hline A9 & $\begin{array}{l}\text { Return on equity ratio - a coefficient equal to the ratio of net profit from sales to the average annual } \\
\text { cost of equity. }\end{array}$ \\
\hline A10 & $\begin{array}{l}\text { Staff turnover rate. Staff turnover rate }=\text { number of laid-off employees for the period under review } \times \\
100 \% \text { / average headcount for the period under review. If the turnover rate exceeds the } 5 \% \text { barrier, the } \\
\text { phenomenon takes on negative features }[3, \text { p.1085-1086]. }\end{array}$ \\
\hline \multicolumn{2}{|r|}{ Section B, increasing corporate social responsibility (CSR) of hotel enterprises } \\
\hline B1 & Contribution to job creation at the district or federal levels \\
\hline $\mathrm{B} 2$ & Quoting jobs for disabled people and giving them discounts \\
\hline B3 & $\begin{array}{l}\text { Providing hotel enterprises with the availability of hotel services; providing them with the necessary } \\
\text { information for people with special needs }\end{array}$ \\
\hline B4 & $\begin{array}{l}\text { The involvement of the local population in the development of hotel enterprises by taking into account } \\
\text { their opinions and suggestions regarding the quality of services provided and the price level }\end{array}$ \\
\hline B5 & $\begin{array}{l}\text { The hotel enterprises have a feedback system with guests, as well as constant timely analysis of negative } \\
\text { reviews and the elimination of problems in a short time }\end{array}$ \\
\hline B6 & $\begin{array}{l}\text { The hotel enterprises have their own crisis and emergency response plan, the main provisions of which } \\
\text { are brought to the attention of local residents, enterprises and visitors }\end{array}$ \\
\hline B7 & $\begin{array}{l}\text { Cooperation with charitable organizations: allocation of funds to sponsor charitable projects, as well as } \\
\text { non-material assistance to the above-mentioned organizations by providing hotel services free of charge }\end{array}$ \\
\hline B8 & $\begin{array}{l}\text { Development and implementation by personnel of hotel enterprises of a sustainable development } \\
\text { management system and periodic training of personnel in their functions and responsibilities }\end{array}$ \\
\hline B9 & Promotional materials for hotel operations should be reliable and respectful to local communities. \\
\hline $\mathrm{B} 10$ & $\begin{array}{l}\text { Preservation by the hotel enterprises of the archaeological, cultural heritage and sacred places in the } \\
\text { vicinity of the hotel enterprises }\end{array}$ \\
\hline
\end{tabular}




\begin{tabular}{|c|c|}
\hline \multicolumn{2}{|r|}{ Section $\mathbf{C}$, hotel business planning with a view to minimizing negative environmental impacts } \\
\hline $\mathrm{C} 1$ & $\begin{array}{l}\text { Identification by the hotel industry of existing threats to the environment and the availability of a ready- } \\
\text { to-use system to counter these threats }\end{array}$ \\
\hline $\mathrm{C} 2$ & $\begin{array}{l}\text { Implementation by hotel enterprises of environmental education of both the local population and hotel } \\
\text { guests, informing them of the importance of preserving the environment }\end{array}$ \\
\hline $\mathrm{C} 3$ & $\begin{array}{l}\text { The implementation by hotel enterprises of energy monitoring to assess, control and reduce energy } \\
\text { consumption }\end{array}$ \\
\hline $\mathrm{C} 4$ & $\begin{array}{l}\text { Adoption of a system for assessing, controlling, minimizing the effects of greenhouse gas emissions [4, } \\
\text { p.212-213 ]. }\end{array}$ \\
\hline $\mathrm{C} 5$ & $\begin{array}{l}\text { Adopting a system for measuring water quality, maintaining statistics on water use and taking measures } \\
\text { for the informed consumption and use of fresh water }\end{array}$ \\
\hline C6 & $\begin{array}{l}\text { The use by hotel enterprises of building materials that provide thermal insulation and reduce energy costs } \\
\text { for heating or cooling }\end{array}$ \\
\hline $\mathrm{C} 7$ & $\begin{array}{l}\text { The introduction of such a system of effective treatment and safe discharge of wastewater, which would } \\
\text { not have a harmful effect on the local population or the environment }\end{array}$ \\
\hline $\mathrm{C} 8$ & $\begin{array}{l}\text { Adoption of a system for measuring and reducing the amount of solid waste (including food waste), the } \\
\text { introduction of separate waste collection }\end{array}$ \\
\hline C9 & Following the green marketing trend in hotel operations \\
\hline $\mathrm{C} 10$ & $\begin{array}{l}\text { The introduction of a system of encouraging guests, employees and suppliers to more widely use } \\
\text { environmentally friendly and efficient transport resources in the activities of hotel enterprises }\end{array}$ \\
\hline \multicolumn{2}{|r|}{$\begin{array}{l}\text { Section D, the creation and enforcement of new laws, both at the hotel industry and at the state level to } \\
\text { ensure the safety of the environment, society and the economy. }\end{array}$} \\
\hline D1 & $\begin{array}{l}\text { Creation by the hotel enterprises of the sustainable development management department within their } \\
\text { organizational structure }\end{array}$ \\
\hline D2 & $\begin{array}{l}\text { Informing hotel enterprises of stakeholders, including guests, about their sustainable development } \\
\text { policies, actions and results }\end{array}$ \\
\hline D3 & $\begin{array}{l}\text { The adoption by hotel enterprises of internal laws that protect the environment of the organization within } \\
\text { the framework of the rules of the organization or within its philosophy or goals }\end{array}$ \\
\hline D4 & Hotel companies minimize pollution from noise, light, runoff and other environmental risks \\
\hline D5 & $\begin{array}{l}\text { Solving the problem of gender inequality by hotel enterprises through the active involvement of women } \\
\text { in economic activity }\end{array}$ \\
\hline D6 & $\begin{array}{l}\text { Compliance by hospitality enterprises with all local, national laws and regulations, including health, } \\
\text { safety and labor }\end{array}$ \\
\hline D7 & $\begin{array}{l}\text { Inclusion in the local regulatory acts on employment of a clause on the need to observe the principle of } \\
\text { equality when hiring employees and following this principle }\end{array}$ \\
\hline D8 & $\begin{array}{l}\text { The exclusion by hotel enterprises of the possibility of a negative impact on the local population, namely } \\
\text { its access to livelihoods, including land and water resources, restrictions on the local population's right } \\
\text { to travel, affordable transportation and housing }\end{array}$ \\
\hline D9 & $\begin{array}{l}\text { Hotel enterprises have a system for regulating visits, especially during the seasonal peak, which would } \\
\text { include measures to preserve, protect and enhance natural and cultural values }\end{array}$ \\
\hline D10 & $\begin{array}{l}\text { Compliance with laws and regulations governing and regulating the display of artifacts in hotel } \\
\text { enterprises }\end{array}$ \\
\hline \multicolumn{2}{|r|}{ Section E, ICT implementation for the effective control and management of hotel enterprises. } \\
\hline E1 & Use by hotel enterprises of energy-saving appliances (water and electricity) \\
\hline E2 & Using technologies that rely on alternative energy, such as solar energy \\
\hline E3 & $\begin{array}{l}\text { The use of technology by hotel enterprises to increase the safety of enterprises and guests. Especially in } \\
\text { cases of danger (arched metal detectors, fire alarms, panic buttons, etc.) }\end{array}$ \\
\hline E4 & $\begin{array}{l}\text { The use of technology to ensure the participation of people with special needs in the activities of hotel } \\
\text { enterprises }\end{array}$ \\
\hline E5 & $\begin{array}{l}\text { Ensuring the availability of high-speed Internet and various services and functions related to the } \\
\text { Internet, such as watching TV via the Internet, including access to various online cinemas in the price } \\
\text { of a room, and others }\end{array}$ \\
\hline
\end{tabular}




\begin{tabular}{|c|l|}
\hline E6 & $\begin{array}{l}\text { Application of the concept of a smart hotel and the concept of Internet of things IoT. Including the } \\
\text { presence of intelligent thermostats and automatic door locks to significantly improve the quality of } \\
\text { guest service }\end{array}$ \\
\hline E7 & $\begin{array}{l}\text { The use of technologies and modern encryption systems to ensure the protection of personal } \\
\text { information of guests, as well as personnel of hotel enterprises }\end{array}$ \\
\hline E8 & $\begin{array}{l}\text { The provision of electronic commerce services; support of banking services (online); cooperation in the } \\
\text { field of electronic banking; and the possibility of payment through an electronic account (PayPal) }\end{array}$ \\
\hline E9 & \begin{tabular}{l} 
Support for the latest e-booking software in hotel operations \\
\hline Eupport for email marketing, websites and social networks. Paying attention to the website design of a \\
hotel company, the means of social communication used and its role in electronic marketing, \\
accessibility in international search engines (Google, Yandex and others)
\end{tabular} \\
\hline
\end{tabular}

Source: designed and compiled by the author based on data from the Global Council on Sustainable Tourism (GSTC)

In our opinion, the classification of criteria for assessing the sustainable development of hotel enterprises is interconnected with the following aspects:

- increase in economic benefits for both hotel enterprises and the local community;

- increase in corporate social responsibility (CSR) of hotel enterprises;

- planning the activities of hotel enterprises with the condition of minimizing negative consequences for the environment;

- creation and compliance with new laws both at the level of hotel enterprises and at the state level to ensure the safety of the environment, society and the economy;

- ICT implementation for the effective control and management of hotel enterprises.

\section{CONCLUSION}

So, the study conducted in this article allows us to come to the following conclusions:

- Sustainable development of hotel enterprises can be defined as comprehensive planning of the responsibilities of all the elements ensuring the formation and functioning of hotel activities in the implementation of sustainable development in the following aspects: economic, social, environmental, institutional and information communication technologies.

- implementation of sustainable tourism development is associated with the implementation of sustainable development in the hotel industry;

- based on the identified criteria for sustainable tourism development for destinations proposed by the Global Council for Sustainable Tourism (GSTC), we have proposed a classification of criteria for assessing the sustainable development of hotel enterprises.

\section{Prospects for the study}

Developing a methodology for assessing the sustainable development of hotel enterprises and creating a new international accreditation system for hotel enterprises in accordance with the sustainable development aspects of hotel enterprises.

\section{REFERENCES}

[1] Kobyak, M.V. Methodological support for the processes of quality management of services in the hospitality industry, M.: Publishing house "Art-Business Center", 2008, 161 p. (in Russian).

[2] Kobyak, M.V., Ilyina E.L., Latkin A.N., Valedinskaya E.N., Evteev M.A. Modern technologies for the promotion of a hotel product, textbook. allowance [for bachelors] M.: Publishing house of REU them. G.V. Plekhanova, 2014, 51 p. (in Russian).

[3] Jarrouj, G. Participation of Employees in Hotel Quality Management, Economics and entrepreneurship. 2019.No 2 (103). S. 1085-1087.m (in Russian).

[4] Jarrouj, G. Improving the Administrative Management of The Hotel by Implementing the International Quality Standard ISO 9001, RISK: Resources, Information, Procurement, Competition. 2018. No. 3. P. 211-215. (in Russian).

[5] Karpunina, E.K., Makhlouf, A.A. The role of tourism and hotel business in ensuring the socio-economic development of the national economy, Socio-economic phenomena and processes. 2017.V. 12. No. 2. P. 64-67. (in Russian).

[6] Karpunina, E.K., Makhlouf, A.A. The influence of social media on the development of tourism and the hotel business, RISK: Resources, Information, Supply, Competition. 2017. No. 2. P. 174-177. (in Russian).

[7] Makhlouf, A. Directions of sustainable development of the hotel business on the example of the Syrian Arab Republic, Materials of the XX International Scientific Conference. New Russian University (Moscow) 2019.S. 113-116. (in Russian). 
Bulletin of the Plekhanov Russian Academy of

[8] Makhlouf, A. Sustainable development: competitiveness factors in the tourism and hospitality industry, Sustainable Development Economics, (Krasnodar), 2019. No. 1 (37), P. 203-206. (in Russian).

[9] Makhlouf, A. Application of information technology as a factor in increasing the competitiveness of a hotel company in conditions of instability (for example, the Syrian Arab Republic), Bulletin of the Russian New University. Series "Man Society", (Moscow) 2019. No. 2. - P. 64-69. (in Russian).

[10] Makhlouf, A. Digital economy, the impact on tourism and hospitality enterprises, Materials of the international scientific-practical conference. "Russian State University of Physical Culture, Sports, Youth and Tourism (SCOLIFK)" (Moscow) 2019.P. 474-477. (in Russian).

[11] Skobkin, S.S. The concept of sustainable tourism development and its impact on the hospitality industry,
Economics. - 2012.-№ 10- S. 77 - 82. (in Russian).

[12] Official site of the United Nations, report of the World Commission on Development Environment [Electronic resource], Access mode: https://www.un.org/en/ga/pdf/brundtland.pdf (accessed: 01.2020)

[13] The official website of the Global Council on Sustainable Tourism (GSTC) [Electronic resource], Access mode: https://www.gstcouncil.org/ (accessed: 01.2020)

[14] Official website of the World Tourism Organization, highlights of international tourism, 2019 edition [Electronic resource], Access mode: www.e-unwto.org/doi/book/10.18111/9789284421152 (accessed: 01.2020) 